\title{
(Auto)Phagocytosis in Atherosclerosis: Implications for Plaque Stability and Therapeutic Challenges
}

\author{
Dorien M. Schrijvers, Guido R.Y. De Meyer and Wim Martinet \\ University of Antwerp, Laboratory of Pharmacology \\ Belgium
}

\section{Introduction}

This chapter is intended to describe the interactions between cell death, phagocytosis and autophagic survival in atherosclerosis, and how these processes could be attractive therapeutic targets for atherosclerotic plaque stabilization.

Atherosclerosis is a long-term, progressive inflammatory disease characterized by the formation of atherosclerotic plaques in the intima of medium- and large-sized arteries. Progression of the disease is accelerated by well-known risk factors including gender, age, hypercholesterolemia, diabetes mellitus, hypertension, smoking, obesity and a sedentary life-style (Kannel et al., 2004). In the advanced stage, plaques can partially or totally occlude the blood vessel, known as arterial stenosis. However, not only the degree of stenosis, but also the composition and stability of the plaque determines the clinical outcome of the disease (Hansson, 2005). Indeed, plaques may become extremely unstable and prone to rupture through the presence of many inflammatory cells and mediators, a large necrotic core consisting of uncleared cell debris and lipids, a high degree of cell death leading to a scarce amount of smooth muscle cells, and the formation of leaky neovessels inside the plaque. Occlusive thrombi, as a result of plaque rupture, in turn cause acute (and often fatal) clinical manifestations, such as myocardial infarction and stroke. Current clinical therapy is focused on chirurgical interventions (stents, endarterectomy, bypass) and plasma cholesterol lowering drugs (e.g. statins). In addition, changes in diet and exercise have made significant inroads in preventing acute atherothrombotic events (Getz \& Reardon, 2006). Although these aforementioned approaches have provided significant improvements, they are far from sufficient. Analysis of the cell death and phagocytosis machinery as well as survival strategies of cells in plaques could provide additional insights for development of new plaque stabilizing strategies.

\section{Phagocytosis of apoptotic cells}

Billions of cells in the human body die each day by the process of apoptosis (Henson et al., 2001). A critical process, called phagocytosis, is coupled with each of these cell death events. Macrophages and nonprofessional phagocytes remove apoptotic cells (AC) via 
phagocytosis in a rapid and efficient manner. This results in at least five critical protective effects: (1) it actively suppresses the secretion of inflammatory cytokines from the phagocyte, via autocrine/paracrine secretion of transforming growth factor beta (TGF $\beta$ ), prostaglandin E2 (PGE2), and platelet-activating factor (PAF) (Fadok et al., 1998), (2) it prevents leakage of proinflammatory intracellular material from the dying cell, before membrane damage occurs, (3) it triggers a potent survival pathway in the phagocyte, involving Akt, NF-кB and cholesterol efflux (Reddy et al., 2002; Kiss et al., 2006), (4) it can promote cell growth and wound healing through the release of vascular endothelial growth factor (VEGF) and TGF $\beta$, respectively (Golpon et al., 2004; Sindrilaru et al., 2009), and (5) it has a vital role in maintaining immunological tolerance against cell-associated antigens, as the TGF $\beta$, produced by the dying cells or the engulfing cells induce the differentiation of inducible regulatory $\mathrm{T}$ cells, which inhibit immune responses (Green et al., 2009). The entire process of phagocytosis (recognition, tethering, binding, internalization) is tightly regulated and involves a wide array of molecules, including receptors on the phagocyte, ligands on the $\mathrm{AC}$ and soluble bridging molecules (Figure 1). The multiplicity of ways in which phagocytes recognize and engulf AC suggests that a hierarchy of engulfment mechanisms and back-up mechanisms exists. Indeed, upon blocking essential receptors phagocytosis of AC is decreased but this inhibition is never complete, suggesting cooperation between different mechanisms of phagocytosis (Pradhan et al., 1997).

Changes in composition and molecular topology of the plasma membrane of the AC involve the loss of "don't-eat-me" signals, also called self-associated molecular patterns (SAMPs), such as CD31 (Brown et al., 2002) and CD47 (Gardai et al., 2005) and the exposure of "eat-me" signals, also known as apoptotic cell-associated molecular patterns (ACAMPs). The most renowned ACAMP is the redistributed phosphatidylserine (PS) (Fadok et al., 1992;, 1999; Callahan et al., 2000; Hoffmann et al., 2001), which on viable cells is actively confined to the inner leaflet of the plasma membrane. Annexin- 1 is a caspase-dependent engulfment ligand that is recruited from the cytosol and exported to the outer plasma membrane leaflet, colocalizes with PS, and is required for efficient clearance of ACs (Arur et al., 2003). Similar to PS, calreticulin acts as a facultative recognition ligand on AC (Martins et al., 2010). Phagocyte pattern recognition receptors such as CD14 (Devitt et al., 1998; Schlegel et al., 1999), scavenger receptors such as CD36, and integrins such as av $\beta 3$ (Savill et al., 1992), together with PS receptors such as BAI-1 (D. Park et al., 2007), TIM-4 (Miyanishi et al., 2007) and stabilin-2 (S.Y. Park et al., 2008), or PS bridging molecules such as MFG-E8 (lactadherin) and Gas-6-which bind to PS on the AC and to integrins or MerTK on the phagocyte, respectively (Qingxian et al., 2010) - are well known phagocytic receptors. Upon engagement, strong tethering is achieved, the phagocytic synapse is set, and engulfment response pathways are activated. Other phagocyte receptors include an unidentified PS receptor (PSR), transglutaminase 2 (TG2) (Szondy et al., 2003), low density lipoprotein receptor-related protein 1 (LRP1) (Lillis et al., 2008), ATP binding cassette 7 (ABCA7), purinergic receptor P2Y2, CD91 (Martins et al., 2010) and fractalkine receptor 1 (CX3CR1).

Recognition signals and receptors are crucial for efficient phagocytosis. However, these signals can only be effective when the phagocyte and the AC are in close proximity. Soluble "come-get-me" signals are secreted by AC to attract phagocytes to sites of AC death (Grimsley \& Ravichandran, 2003) (Table 1). 


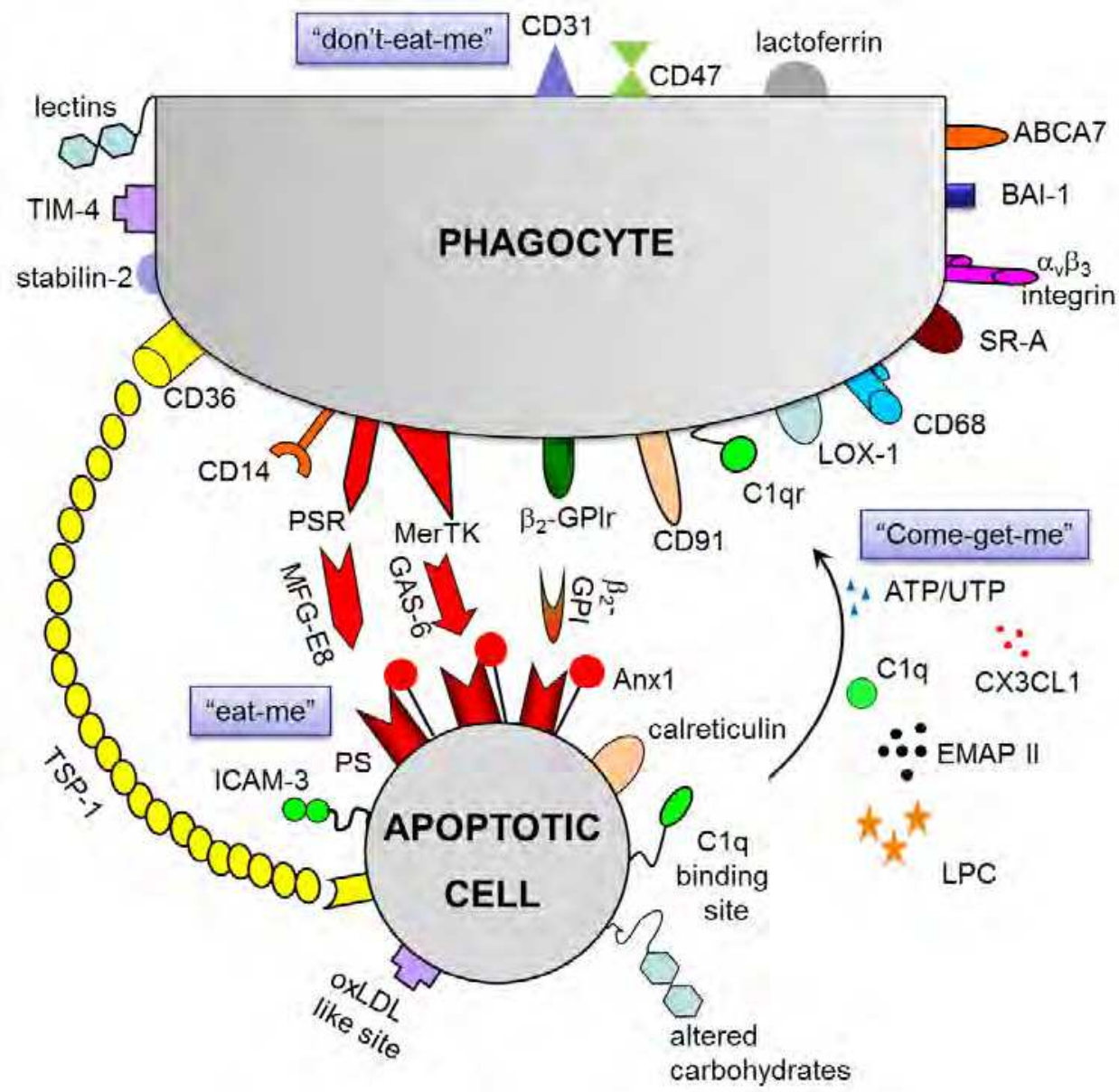

Fig. 1. Phagocyte recognition of apoptotic cells. Several receptors on the phagocyte membrane are involved and interact either directly with their ligands on the AC surface ("eat-me") or via bridging molecules. AC can send out chemoattractant signals to attract macrophages to the site of cell death ("come-get-me"). To prevent phagocytosis of healthy cells, the latter express molecules to identify themselves ("don't-eat-me"). ABCA7, ATPbinding cassette-7; CD14, lipopolysaccharide receptor; LOX-1, lectin-like oxidized low density lipoprotein receptor-1; CD36, thrombospondin receptor; CD68, macrosialin; SRA, scavenger receptor class $A ; F c R, F c$ fragment of immunoglobulin $G$ receptor; LRP, LDL receptor-related protein; CD91, $\alpha 2$-macroglobulin; GAS-6, growth arrest-specific gene 6; $\beta 2$ GPI, beta 2-glycoprotein 2; TSP, thrombospondin; PS, phosphatidylserine; PSR, PS receptor; $\alpha v \beta 3$, vitronectin receptor; MFG-E8, milk-fat globule epidermal growth factor 8; ICAM-3, intracellular adhesion molecule-1; C1q, complement complex 1q; Anx1, annexin 1; BAI-1, brain angiogenesis inhibitor-1; TIM-4, T-cell immunoglobulin and mucin domain-containing protein 4; MerTK, c-mer proto-oncogene tyrosine kinase; LPC, lysophosphatidylcholine; CX3CL1, fractalkine; EMAP II, endothelial monocyte-activating polypeptide II. 
The first identified attraction signal of AC was the covalent dimer of ribosomal protein S19 (dRP S19) (Horino et al., 1998). It is an essential monocyte chemoattractant in the synovium of patients with rheumatoid arthritis (Nishiura et al., 1996). By using neutralizing antibodies, G-protein coupled receptor CD88 was identified as a crucial receptor for dRP S19. The most characterized AC-derived attractant is lysophosphatidylcholine (LPC), which is secreted in a caspase-3 dependent manner (Lauber et al., 2003). LPC exerts its chemotactic effect on monocytes via the G-protein coupled receptor G2A (Peter et al., 2008). Knockout mice that are deficient in G2A develop a typical autoimmune phenotype resembling systemic lupus erythematosus, which was already known to be caused by deficiencies in AC recognition (Le et al., 2001). Another AC-derived attraction signal is the endothelial monocyte-activating polypeptide II (EMAP II) that is proteolytically cleaved during apoptosis but not during necrosis to mature and release the active p23 protein (Knies et al., 1998). Processing of pro-EMAP II was observed to be a rather late event in the course of apoptosis, occurring several hours after poly (ADP-ribose) polymerase cleavage. Since AC are phagocytised at an early stage, it was suggested that mature EMAP II serves as a backup signal at sites of excessive cell death (Behrensdorf et al., 2000). Importantly, in vitro experiments showed that human pro-EMAP II is not cleaved by caspases and mature EMAP II could not be found in AC, as opposed to murine EMAP II. Thus, it is not entirely clear whether mature EMAP II or its precursor is the real cytokine (Martinet et al., 2010). The only receptor that has been reported in the context of EMAP II is CX3CR1, but it remains to be elucidated whether this is the crucial sensor for EMAP II p23 (Hou et al., 2006). C1q facilitates the ingestion of apoptotic cells by human macrophages via binding to calreticulin (Ogden et al., 2001). Thrombospondin-1 (TSP1) modulates a number of processes, including migration, proliferation and angiogenesis and was also found to be actively secreted during apoptosis (Savill et al., 1992). It serves as a bridging molecule to physically connect the phagocyte to the $\mathrm{AC}$, though the phagocyte sensor involved remains obscure. Recently, nucleotides such as ATP and UTP, which can be recognized by purinergic receptor P2Y2, were found to be released from $\mathrm{AC}$ and incite migration of monocytes and macrophages (Elliott et al., 2009). Membrane-bound fractalkine (CX3CL1) can be released from AC by a so far unknown protease, to induce recruitment of macrophages (Truman et al., 2008). The CX3CR1-fractalkine system seems to be particularly important in germinal centers, and is limited to certain cell types, such as B cells and neurons. Two less characterized AC-derived chemokines are sphingosine-1-phosphate (S1P) and the N-terminal fragment of tyrosyl tRNA synthetases (mini TyrRS) (Gude et al., 2008; Wakasugi \& Schimmel, 1999). Both were identified in in vitro settings and might contribute to the anti-inflammatory character of AC clearance. While it is clear that apoptosis can be executed in the absence of blebbing and that phagocytic engulfment is not restricted to 'bite-sized' apoptotic bodies, it has been suggested that fragmentation of the AC may be important for chemotactic signaling to mononuclear phagocytes (Segundo et al., 1999; Hugel et al., 2005; Simons \& Raposo, 2009). Yet, the range of action and the phagocyte sensors remain to be resolved.

Note that plasma membrane-damaged cells (i.e. late apoptotic and necrotic cells) can also release or expose endogenous and exogenous signals, known as alarmins or damageassociated molecular patterns (DAMPs), to alert the organism to tissue injury (Patel et al., 2006; Peter et al., 2010) (Table 1). One such protein is the high mobility group box 1 protein (HMGB-1), which is released from necrotic cells, but not during apoptosis, and actively stimulates the secretion of proinflammatory cytokines (Scaffidi et al., 2002; Andersson et al., 
2000). Toll like receptors (TLR)-2 and 4 have been described to be engaged in HMGB-1 signaling (Yu et al., 2006). Another necrotic cell-derived danger signal, that is closely related to HMGB-1 is the hepatoma-derived growth factor (HDGF) (Nakamura et al., 1994). It is mainly located in the nucleus and remains trapped there during apoptosis, but is passively released during necrosis. The family of the calgranulin proteins, also referred to as the S100 proteins, are potent chemoattractant proteins and play a significant role in the propagation of inflammation (Donato, 2003; Foell et al., 2008). Specifically, the S100A8-S100A9 complex and S100A12 proved to be useful diagnostic markers of inflammatory diseases, like arthritis and COPD, where they are found in high concentrations in the blood, sputum, stool and synovial fluid (Foell et al., 2004). Future studies need to clarify whether these proteins also represent therapeutic targets. Heat shock proteins (HSP) 70, 90 and 98 are released during heat-induced necrosis, probably via exosomes (Basu et al., 2000). Yet, knowledge about the secretion and exact functions is confusing and needs clarification. For example, apart from their TLR-mediated pro-inflammatory signaling, HSP also display anti-inflammatory effects (Wieten et al., 2007; Tang et al., 2007). Finally, concentrations of uric acid are increased during cell injury. Uric acid has the ability to prime $\mathrm{T}$ cells in the generation of helper and cytotoxic T cells (Shi et al., 2002; Ghaemi-Oskouie \& Shi, 2011).

\begin{tabular}{|l|l|l|l|}
\hline \multicolumn{1}{|c|}{ "don't-eat-me" } & \multicolumn{1}{|c|}{ "eat-me" } & \multicolumn{1}{|c|}{ "come-get-me" } & \multicolumn{1}{c|}{ "alarmins" } \\
\hline CD31 & PS & LPC & HMGB-1 \\
\hline CD47 & Anx1 & EMAP-II (p23) & HDGF \\
\hline lactoferrin & calreticulin & ATP/UTP & S100 proteins \\
\hline & & TSP1 & HSPs \\
\hline & & CX3CL1 & uric acid \\
\hline & & C1q & \\
& & dRP S19 & \\
& & mini TyrRS & \\
& & S1P & \\
& & microblebs & \\
\hline & &
\end{tabular}

Table 1. Comprehensive list of signals that are presented and/or secreted by healthy cells ("don't-eat-me"), apoptotic cells (cell surface "eat-me" signals and soluble "come-getme"signals) or necrotic cells ("alarmins"). Abbreviations: PS, phosphatidylserine; Anx1, annexin 1; LPC, lysophosphatidylcholine, EMAP-II (p23), endothelial monocyte-activating polypeptide II active protein; TSP1, thrombospondin 1; CX3CL1, fractalkine; C1q, complement complex 1q; dRP S19, dimer of ribosomal protein S19; mini TyrRS, N-terminal fraction tyrosyl tRNA synthetase; S1P, sphingosine-1-phosphate; HMGB-1, high mobility group box 1 protein; HDGF, hepatoma-derived growth factor; S100 proteins, calgranulin family of proteins; HSP, heat-shock protein.

Recognition of necrotic cells by phagocytes is less well understood than recognition of ACs, but an increasing number of recent studies are highlighting its importance. (Krysko et al., 2006). C1q, mannose-binding lectin (MBL) and pentraxin-3 (PTX3) were demonstrated exclusively on late ACs and necrotic cells (Gaipl et al., 2001; Nauta et al., 2003; Rovere et al., 2000). C-reactive protein (CRP), an acute phase protein binds to secondary necrotic neutrophils (Hart et al., 2005). However, CRP does not uniquely bind to necrotic cells. The 
same is true for TSP1. Future studies are needed to identify the differences and similarities between the macrophage interaction with AC and necrotic cells. A pitfall in this area is the lack of a good cell culture system to study this. Current cell culture models are still very variable, displaying a mixture of early and late ACs and necrosis. In addition, detailed information on mechanisms of binding and internalization of necrotic cells is sparse. Importantly, the trigger provoking necrotic death has an important impact on the kind of immunological response of phagocytes (Hirt \& Leist, 2003). Phagocytic uptake of late apoptotic/necrotic cells by antigen-presenting cells, such as DCs, can lead to the presentation of autoantigens to autoreactive $\mathrm{T}$ cells in a proinflammatory context, thus facilitating the onset of an autoimmune response (Poon et al., 2010). However, there are several studies reporting non-inflammatory responses of phagocytes, including modulation of anti-tumor immunity and tissue repair via VEGF induction (M. Li et al., 2001).

For more comprehensive details of the molecular complexity of the clearance phases and engulfment signaling pathways, the reader is referred to recent reviews (Elliott \& Ravichandran, 2010; Kinchen 2010; Poon et al., 2010; Devitt \& Marshall, 2011).

\subsection{Phagocytosis of apoptotic cells in atherosclerosis}

In early human atherosclerotic plaques, phagocytic clearance of AC by macrophages is very efficient (Tabas, 2005) (Figure 2). Conversely, phagocytosis in advanced human atherosclerotic plaques is defective, resulting in secondary necrosis, expansion of the necrotic core and increased plaque vulnerability (Schrijvers et al., 2005; Thorp \& Tabas, 2009; Thorp, 2010). Similar results have been found in mouse models of advanced atherosclerosis. The impact of defective clearance of $\mathrm{AC}$ on the plaque further exacerbated when essential effector molecules in phagocytosis were targeted. Examples of these effector molecules are MerTK (Thorp et al., 2008; Ait-Oufella et al., 2008), MFG-E8 (Ait-Oufella et al., 2007), C1q (Bhatia et al., 2007), LRP-1 (Yancey et al., 2010), TSP1 (Moura et al., 2008), TG2 (Boisvert et al., 2006) and ABCA7 (Jehle et al., 2006).

The mechanisms of defective phagocytosis in advanced atherosclerotic plaques are not entirely clear, although in vitro experiments have put forward several plausible explanations (Schrijvers et al., 2005). It is unlikely that overwhelming apoptosis is a major factor, since phagocytosis is very efficient in early plaques, where phagocytosis is not defective, when excessive apoptosis is induced through genetic manipulation (Tabas, 2010). In addition, AC in plaques are found in the vicinity of macrophages, which rules out a possible geographic problem. Moreover, atherosclerotic plaques are highly inflamed tissue and contain large areas of macrophage infiltration. Therefore, it is not the quantity of the phagocytes that is important for phagocytosis, but their functionality. Most likely, phagocytosis itself becomes ineffective in advanced plaques.

One of the first discovered mechanisms that contribute to defective clearance of AC in atherosclerosis is the competition of oxidized low density lipoproteins (oxLDL), but not acetylated LDL, with AC and oxidatively damaged cells for macrophage binding (Sambrano \& Steinberg, 1995). AC, oxLDL as well as oxidized red blood cells share oxidatively modified moieties on their surfaces that serve as ligands for macrophage recognition, thereby profoundly inhibiting the phagocytosis of AC. Furthermore, secretion of MFG-E8 (lactadherin), a macrophage-derived molecule that facilitates phagocytosis of AC, is downregulated upon free cholesterol-loading in macrophages (Su et al., 2005). Electron microscopy images from macrophage-derived foam cells in atherosclerotic plaques show 
that these cells are often crammed with large lipid droplets. It is therefore tempting to speculate that these macrophages are no longer able to engulf AC ("full is full"). Uptake of AC in macrophages treated in vitro with an excess of platelets or aggregated LDL is not inhibited, most likely because foam cells in culture rarely reach the same degree of foam cell formation as seen in human plaques, but phagocytosis of beads results in a nearly complete inhibition of phagocytosis of AC (Schrijvers et al., 2005). These findings confirm a study by Moller et al. (2002) showing that uptake of indigestible, rigid particles by macrophages induces cellular 'stiffening' so that changes in cellular shape, which are needed to form pseudopodia for phagocytosis, are inhibited. In addition to foam cell formation, increased oxidative stress is a hallmark of advanced atherosclerotic plaques. Although several reactive oxygen species (ROS) can be found in human plaques, peroxynitrite (ONOO-) plays a central role in the pathophysiology of atherosclerosis as it induces protein nitrosylation and oxidative DNA damage. The peroxynitrite donor SIN1A concentration-dependently decreases phagocytosis of AC in vitro (Schrijvers et al., 2005), suggesting that PS or other factors present on macrophages or dying cells required for phagocytosis may be sensitive to oxidative conditions. Proteolytic cleavage of macrophage receptors exacerbates disease in cystic fibrosis and bronchiectasis (Vandivier et al., 2002). Potent proteases, such as matrix metalloproteinases and ADAM proteins (a disintegrin and metalloproteinase) are upregulated in advanced plaques. In vitro cleavage of MerTK leads to generation of soluble Mer, that binds to AC and prevents their uptake by macrophages (Sather et al., 2007). Interestingly, gene polymorphisms in CD31 ("don't eat me") and increasing levels of its soluble form have been associated with ischemic stroke, suggesting that extracellular CD31 could affect phagocyte interactions with AC (Wei et al., 2009). These, and other ideas, will require careful assessment in advanced atherosclerotic plaques.

The accumulation of $\mathrm{AC}$ has a number of consequences that promote plaque progression and destabilization (Figure 2). Firstly, impaired phagocytosis of AC results in enhanced secretion of proinflammatory cytokines including TNFa and IL- 6 by the phagocyte, and a reduced release of anti-inflammatory proteins such as TGF $\beta$ and IL-10 (Fadok et al., 1998; Erwig \& Henson, 2007). Deregulated expression of these cytokines may result in inflammatory autoimmune responses, as seen in systemic lupus erythematosus and rheumatoid arthritis, two non-atherosclerotic inflammatory disorders with a similar defect in phagocytosis of dying cells by macrophages. Secondly, tissue factor (TF) expression colocalizes with $\mathrm{AC}$, especially around the lipid core of human atherosclerotic plaques, suggesting that uncleared AC are an important source of this molecule (Tedgui \& Mallat, 2001). TF is a key element in the initiation of the coagulation cascade and mediates thrombus formation after rupture of an unstable plaque, when free $\mathrm{AC}$ are exposed to the blood stream. Thirdly, macrophages that have ingested cholesterol-loaded AC show a remarkable set of survival responses, some of which are not present during the loading of macrophages with lipoprotein-derived cholesterol (Cui et al., 2007). These responses include cholesterol esterification and massive cholesterol efflux, as well as the triggering of cell survival signal transduction pathways involving PI3-kinase/Akt and NF- $\mathrm{kB}$. Consequently, impaired phagocytosis of AC renders the phagocyte more susceptible to cholesterol-induced death (Yvan-Charvet et al., 2010). Finally, expansion of the necrotic core is stimulated due to secondary necrosis of free AC. The interaction of macrophages with necrotic cells or compounds released from necrotic cells (alarmins) often results in an additional inflammatory response (Scaffidi et al., 2002). Necrotic cells also passively release matrix 
degrading proteases. In this way, post-apoptotic necrosis may contribute to plaque instability through enlargement of the necrotic core, matrix breakdown and stimulation of inflammation and neovascularization (Figure 2).

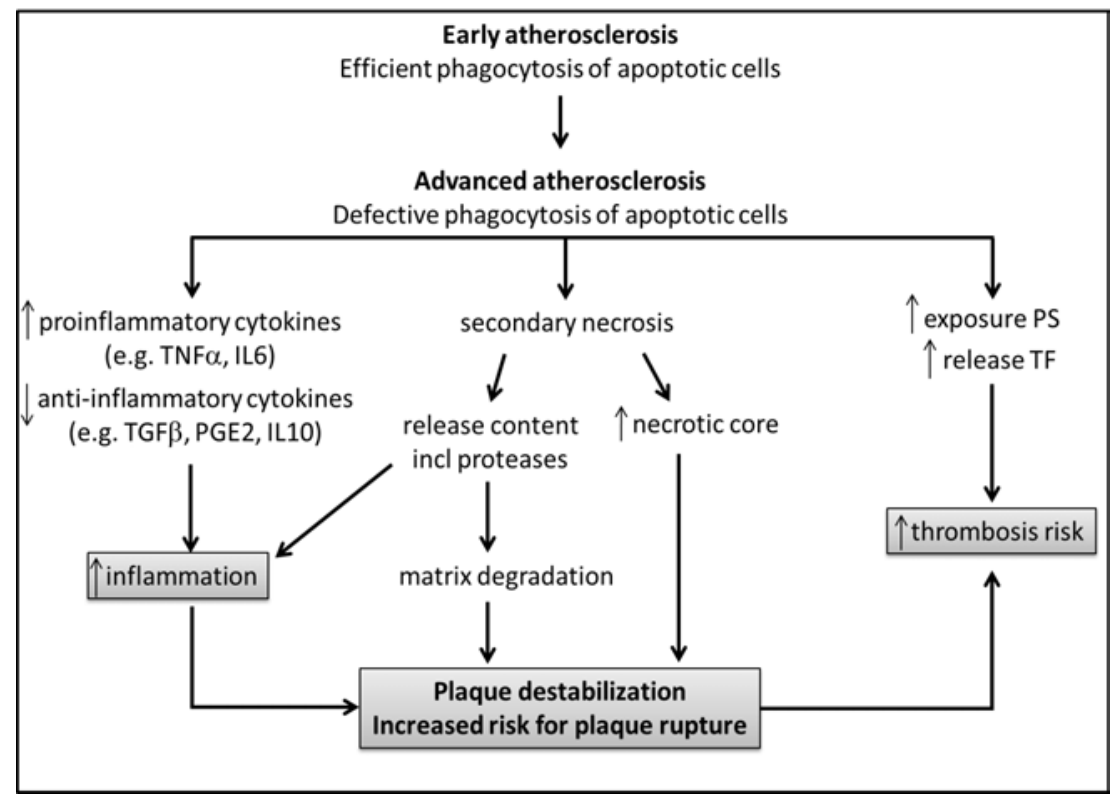

Fig. 2. Consequences of defective phagocytosis of apoptotic cells in atherosclerotic plaques. In early plaques, $\mathrm{AC}$ numbers are low and phagocytosis is very efficient, which stimulates active suppression of inflammatory pathways, prevents release of intracellular contents from the dying cells and promotes macrophage survival. In advanced plaques however, phagocytosis of ACs is severely impaired, leading to plaque progression and destabilization through various mechanisms. Unstable plaques are at risk for rupture, which results in the formation of an occlusive thrombus and subsequent, possible fatale, ischemic events. In addition, ACs expose phosphatidylserine (PS) and are a source of tissue factor (TF), both highly thrombogenic.

\subsection{Therapeutic possibilities}

Defective AC clearance can alter immune responses in ways that exacerbate human diseases, e.g. acceleration of SLE, COPD, cystic fibrosis and atherosclerosis. Therefore, a promising approach to stabilize atherosclerotic plaques would be to therapeutically enhance the phagocytic capacity of macrophages. Importantly, non-specific enhancement of phagocytosis is not desirable, because of the adverse effects associated with phagocytosis of lipoproteins, platelets or erythrocytes (Schrijvers et al., 2007).

Statins are an important class of drugs in the treatment of atherosclerosis. They were discovered as drugs that reduce cholesterol levels by inhibiting the 3-hydroxy-3methylglutaryl coenzyme A (HMG-CoA), but they also have an anti-inflammatory action by virtue of their ability to block prenylation of signaling molecules, i.e. Rho GTPases. Interestingly, it has been shown that lovastatin increases phagocytosis of ACs by 
macrophages from COPD patients in an HMG-CoA reductase-dependent manner (Morimoto et al., 2006). In contrast, simvastatin impairs Fc-receptor mediated phagocytosis of bacteria (phagocytosis followed by oxidative burst and bacterial killing) and at the same time enhances the production of proinflammatory mediators (Benati et al., 2010). These data should be assessed to prevent potential side-effects in patients undergoing long-term treatment with this statin, who become exposed to an opportunistic pathogen such as $S$. aureus, that is commonly found on the skin and in the upper airways.

Because oxLDL or oxLDL antibodies interfere with phagocytosis of $\mathrm{AC}$, it is tempting to speculate that antioxidants can improve clearance of dying cells. However, clinical trials in humans with antioxidants showed only limited success in preventing coronary artery disease. Possibly the antioxidants lose activity too quickly or do not penetrate the plaque deep enough to reach the phagocytes. This idea is supported by the fact that antioxidants do not prevent the oxidation of phagocytized lipoproteins in the lysosome of macrophages (Wen \& Leake, 2007). It is possible that more encouraging results will be obtained in the future through the use of drugs that are targeted to specific oxidation reactions in atherosclerosis. It should also be noted that certain antioxidants may not promote but inhibit recognition of AC by phagocytes by inhibiting oxidation of externalized PS (Tyurina et al., 2004).

In obesity and type 2 diabetes, the defect in efferocytosis of macrophages seems to be related to increased concentrations of saturated fatty acids (FA) and/or decreased concentrations of the $\omega$-3 FA eicosapentaenoic acid (EPA) and docosahexaenoic acid (DHA) (S. Li et al., 2009). This change in membrane lipid composition may lead to defective PI3K activation and failure to generate PIP3 in the macrophage phagocytic membrane. Interestingly, feeding $\mathrm{ob} / \mathrm{ob}$ mice a fish oil diet increases $\omega-3$ FA without appreciable changes in the content of saturated FA and leads to a reversal of the defect in efferocytosis and a reduction in plaque size (S. Li et al., 2009). These findings suggest that the level of $\omega-3$ FA in the macrophage membrane is an important factor contributing to efficient efferocytosis.

Examples of other drugs that promote phagocytic clearance of AC are chemerin, an endogenous chemoattractant (Cash et al., 2010), the macrolide antibiotic azithromycin (Hodge et al., 2006), members of the lipoxin family (Godson et al., 2000), inflammation resolution mediators such as resolvins (Serhan et al., 2008), inhibitors of MerTK cleavage (Sather et al., 2007), PPAR $\delta$ activators (Mukundan et al., 2009), LXR activators which increase expression of MerTK, as well as compounds that induce secretion of the efferocytosis effector apolipoprotein E and ABCA1/G1-mediated efflux of toxic sterols (AGonzalez et al., 2009; Yancey et al., 2010; Yvan-Charvet et al., 2010).

Phagocyte populations in atherosclerosis are heterogeneous (Waldo et al., 2008; Shimada, 2009) and express different express markers and phagocytic receptors, depending on their spatial location in the plaque and surrounding milieu. In vitro, alternatively activated macrophages (M2 phenotype) preferentially clear AC and secrete anti-inflammatory cytokines, including IL-10 and TGF $\beta$ (W. Xu et al., 2006). On the other hand, classically activated (M1) macrophages secrete proinflammatory cytokines, such as TNF $\alpha$ and IL-6, that can negatively affect phagocytosis. It would be interesting to elucidate whether communication between these subsets affects phagocytosis efficiency. Plaque phagocytes can polarize towards a spectrum of activation states, resulting in altered phagocytic capacities (Peng et al., 2009). Taking advantage of the fact that some subpopulations are more efficient phagocytes, might be a very attractive way to restore and enhance defective 
AC clearance in atherosclerotic plaques. For example, activation of PPAR $\gamma$ stimulates macrophage polarization to the anti-inflammatory M2 phenotype (Bouhlel et al., 2007). Whether or not these aforementioned approaches will be effective at stabilizing atherosclerotic plaques through the amelioration of phagocytic clearance remains to be elucidated.

\section{Autophagy}

\subsection{General principles}

While phagocytosis reflects clearance of non-self particles, autophagy represents a process for cells to dispose of their own unwanted or damaged proteins and organelles (Klionsky, 2007). Autophagy or "self eating" refers to a conserved cellular process for the turnover of organelles and proteins that occurs in all eukaryotic cells (Yoshimori, 2004). It is activated as an adaptive response to environmental stress (e.g. nutrient deprivation, hypoxia, oxidative stress, exposure to xenobiotics) to promote cell survival through the recycling of precursors (amino acids, free fatty acids, nucleotides) derived from the degradation of endogenous cellular components. Typical of autophagy is the formation of double-membrane structures, called phagophores, that engulf intracellular material such as protein aggregates, lipid droplets and complete organelles for degradation (Figure 3). The phagophore expands and, on completion, forms an autophagosome, which then fuses with lysosomes, thereby generating an autophagolysosome (Shintani \& Klionsky, 2004). Incorporation of the outer autophagosomal membrane in the lysosomal membrane allows the degradation of the remaining inner single membrane and the cytoplasmic content of the autophagosome by lysosomal hydrolases.

Autophagy generally acts as a housekeeping mechanism, and is crucially involved in the maintenance of normal cellular homeostasis. Hereby, turnover of damaged or dysfunctional organelles, such as mitochondria, peroxisomes and endoplasmic reticulum, is facilitated to maintain a healthy population of these organelles. When stimulated by cellular stress conditions, autophagy functions as a self-cannibalization pathway that promotes cell survival in an unfavorable environment. This pro-survival function of autophagy has been demonstrated at the cellular and tissue level in different contexts, such as nutrient and growth factor deprivation, endoplasmic reticulum stress, development, microbial infection, and diseases characterized by the accumulation of protein aggregates. Preclinical studies have demonstrated that autophagy is associated with cancer, neurodegenerative disorders (e.g. Alzheimer's, Parkinson's and Huntington's disease), embryogenesis, aging and immunity, but also with cardiovascular disease including ischemia-reperfusion injury of the heart, cardiomyopathy and atherosclerosis (Mathew et al., 2007; Levine \& Kroemer, 2008; Mizushima et al., 2008; Martinet \& De Meyer, 2008,2009a). Despite tremendous recent advances in this field, the functional significance of autophagy in human disease remains incompletely understood, and potentially involves both adaptive and maladaptive outcomes.

There are three main types of autophagy, namely macroautophagy, microautophagy or chaperone-mediated autophagy (Klionsky et al., 2007). Macroautophagy is the most extensively analysed and quantitatively more important type of autophagy in which entire portions of the cytosol are sequestered by a de novo-formed phagophore that seals into an autophagosome (Figure 3). In addition to this 'in bulk' degradation, selective sequestration of cellular structures into autophagosomes is a common mechanism for removal of 
organelles or particulate protein complexes (aggregates). This is then referred to as selective macroautophagy. The process of microautophagy is poorly characterized, at least in mammalian cells. Like in macroautophagy, entire cytosolic regions constitute the microautophagy cargo, but it is the lysosomal membrane itself that invaginates or protrudes to seclude the cytosolic components. Selective autophagy of soluble cytosolic proteins can occur via chaperone-mediated autophagy, the only type of autophagy that requires unfolding of the protein cargo before internalization into lysosomes (Dice, 2007). Selectivity is determined via the recognition of a pentapeptide in the amino acid sequence of the substrate proteins that are delivered to the surface of the lysosomes by a cytosolic chaperone (Hsc70). To reach the lysosomal lumen, these proteins interact with the lysosome-associated protein type $2 \mathrm{~A}$ (LAMP-2A) receptor, and a complex of lysosomal chaperones at both sides of the lysosomal membrane.

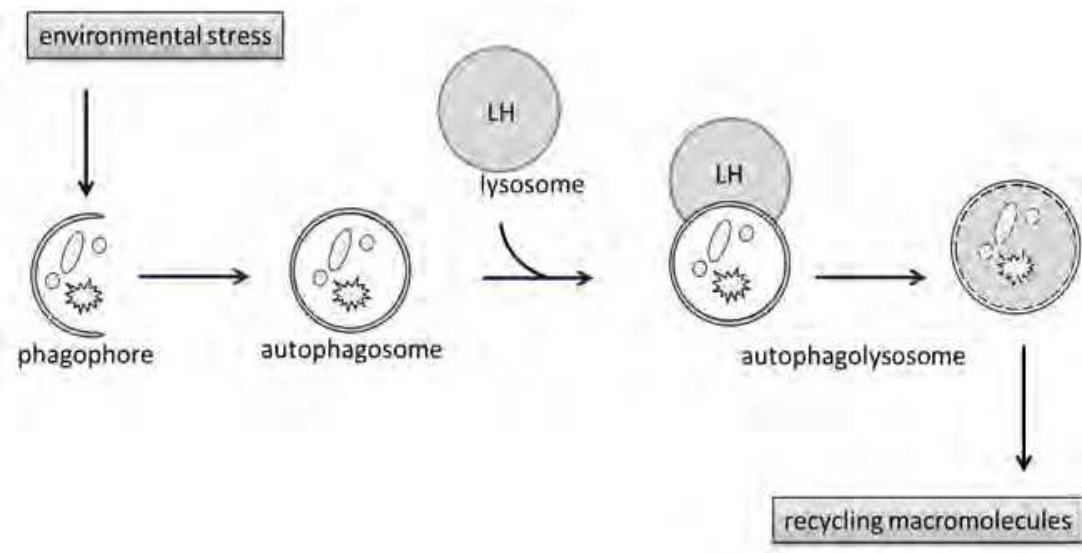

Fig. 3. Schematic depiction of the autophagy process. A phagophore is formed at the initiation of autophagy, in response to environmental stress (e.g. nutrient deprivation) to sequester cytoplasmic components for degradation. Upon completion, the phagophore forms a double-membraned vesicle called an autophagosome. After fusion with a lysosome, the content is degraded by lysosomal hydrolases (LH). Following breakdown, the resulting macromolecules (e.g. nucleic acids, amino acids, free fatty acids) are released back into the cytosol for reuse by the cell.

\subsection{Molecular mechanisms of autophagy}

The molecular machinery and signaling cascades that regulate autophagy are very complex (Ravikumar et al., 2010; Yang \& Klionsky, 2010). Briefly, the key regulator of autophagy in human and murine cells is the mammalian target of rapamycin (mTOR) kinase, which suppresses autophagy in conditions of sufficient nutrients and growth factors, via class I phoshatidylinositol-3-kinases (PI3Ks) and Akt. Activation of the mTOR complex 1 (mTORC1) - and consequent repression of autophagy - can also be mediated by mitogenactivated protein kinases (MAPKs), by activation of the p90 ribosomal S6 kinase, as well as by the Wnt signaling pathway. Other prominent regulators of autophagy include (but are not limited to): AMP-activated protein kinase (AMPK), which inhibits mTOR in response to reduced ATP levels; eukaryotic translation initiation factor $2 \alpha(\mathrm{eIF} 2 \alpha)$, which responds to 
nutrient deprivation; c-Jun N-terminal kinase (JNK), which is involved in multiple signaling cascades activated by stressful conditions; members of the Bcl-2 protein family that contain a single Bcl-2 homology $(\mathrm{BH})$ domain, the so-called BH3-only proteins, which displace (and hence derepress) the essential autophagy modulator Beclin 1 from inhibitory complexes with Bcl-2 or Bcl-XL; Sirtuin 1, which responds to high NAD+ levels, de facto acting as a sensor of nutrient availability; the oncosuppressor protein p53, which inhibits autophagy when present in the cytoplasm; the IKB kinase (IKK) complex, which is also essential for the activation of NF-kB by stress; the inositol 1,4,5-trisphosphate (IP3) receptor (IP3R) at the level of the ER and transglutaminase 2. Finally, autophagy is positively regulated by the transcription factor activity of E2F1, FoxO3a, NF-kB and p53 among others.

\subsection{Autophagy in atherosclerosis}

Autophagy in atherosclerotic plaques has not yet been analysed in full detail due to technical limitations, in particular the lack of adequate marker proteins. As a consequence, the role of autophagy in atherosclerosis is unclear and currently under intense investigation. However, transmission electron microscopy of smooth muscle cells (SMCs) in the fibrous cap of advanced plaques revealed ultrastructural features of autophagy such as vacuolization and formation of myelin figures (Martinet \& De Meyer, 2009b). The latter structures, composed of phospholipids and membrane fragments, refer to autophagic degradation of membranous cellular components. Moreover, Western blot analysis of human carotid plaques showed processing of microtubule-associated protein 1 light chain 3 (LC3) into the autophagosome-specific isoform LC3-II, indicating activation of autophagy. Importantly, these kind of data have to be interpreted with great caution. Autophagy is a dynamic process: formation of autophagosomes, followed by their degradation after lysosomal fusion (Figure 3). Many groups, including our own, have measured increased autophagosome formation or LC3 processing, and labelled this as increased autophagic activity. However, these parameters can also reflect impaired degradation. Therefore, it is essential to measure autophagic flux (Gottlieb \& Mentzer, 2010). In tissue, this can be very challenging. A very elegant method now widely accepted to measure flux is using a tandem fusion protein of LC3 with the red acid-insensitive mCherry (or RFP) and the green acidsensitive GFP proteins to measure formation of autolysosomes and their degradation (Kimura et al., 2007). GFP fluorescence is quenched in the acidic environment of the lysosome, while mCherry (or RFP) fluorescence is stable at low $\mathrm{pH}$. As a consequence, detection of yellow fluorescence (overlap of GFP and mCherry) reflects impaired flux, and the presence of red fluorescence reflects quenching of GFP and thus ongoing degradation in the lysosome (Mizushima et al., 2010). Besides LC3, levels of other autophagy substrates can be used for measuring autophagic flux, of which the best studied is p62, an adaptor protein that links ubiquitinated proteins to LC3. Accumulation of p62 reflects impaired degradation in the autophagolysosome, whereas low p62 levels indicate active degradation. Unfortunately, no data is available on p62 levels during atherosclerotic plaque formation and destabilization.

In vitro studies identified several potential triggers for autophagy that are present in atherosclerotic plaques, such as inflammation (Heymann, 2006; Jia et al., 2006), ROS production (Scherz-Shouval \& Elazar, 2011), accumulation of oxidized lipoproteins (Muller et al., 2011; Nowicki et al., 2007) and endoplasmic reticulum stress (Qin et al., 2010). Also hypoxia is a common feature of advanced human atherosclerotic plaques (Sluimer et al., 
2008), caused by inadequate vascularization, nutrient and growth factor deprivation, a wellknown condition leading to induction of autophagy (Azad et al., 2008).

\subsubsection{Dual role of autophagy in atherosclerosis}

Autophagy can protect plaque cells against oxidative stress by degrading damaged intracellular material, in particular polarized mitochondria (Kiffin et al., 2006). In this way, successful autophagy of the damaged components promotes cell survival by limiting the release of pro-apoptotic proteins such as cytochrome c into the cytosol (Gozuacik \& Kimchi, 2004). The protective role of autophagy in atherosclerosis was illustrated by in vitro findings showing that death of smooth muscle cells (SMC) induced by low concentrations of statins is attenuated by the autophagy inducer 7-ketocholesterol (Martinet et al., 2008). Also excess free cholesterol or exposure of SMCs to lipid peroxidation products such as 4hydroxynonenal activates autophagy, thereby prolonging SMC survival (K. Xu et al., 2010). Also, autophagy safeguards efficient phagocytosis of AC (Qu et al., 2007), which is beneficial for plaque stability (Figure 2). Altogether, induction of autophagy represents a vital component of a general stress response in vascular cells and could therefore be an important determinant of the stability of atherosclerotic plaques (Figure 4).

In contrast, excessive autophagy in SMCs or endothelial cells may cause autophagic cell death (Levine \& Yuan, 2005). SMC death in turn results in plaque destabilization owing to the reduced synthesis of collagen and thinning of the fibrous cap. Also endothelial cell death may be detrimental for the structure of the plaque as endothelial injury and/or death represents a primary mechanism for acute clinical events by promoting lesional thrombosis. In view of plaque stability and regression, these observations might advise against excessive autophagy induction in plaques. Conversely, autophagic death of macrophages is considered a promising approach to stabilize advanced plaques (Martinet et al., 2007).
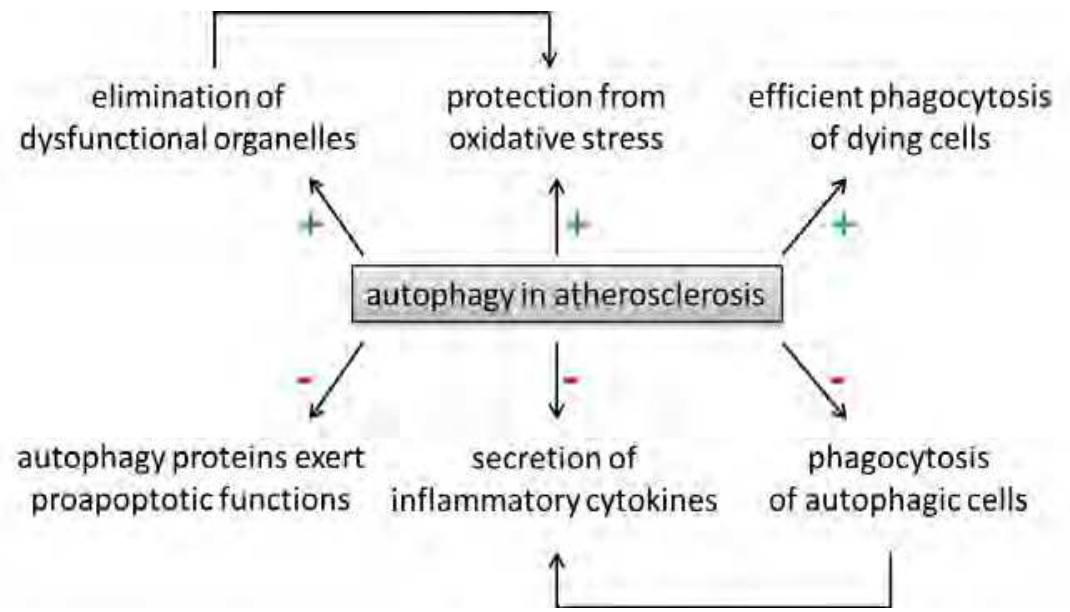

Fig. 4. Consequences of autophagy in atherosclerosis. While autophagy contributes beneficially to plaque stability by protecting cells from oxidative stress and ensuring efficient clearance of dead cells, it can also exert functions that are unfavorable in terms of plaque stability. Autophagy has a very potent inflammatory component and is very tightly linked to other forms of cell death, especially apoptosis. 
However, recent evidence indicates that phagocytosis of cells dying through autophagy results in an inflammatory response through inflammasome activation, IL-1 $\beta$ release and subsequent IL-6 and TNF $\alpha$ induction in neighboring phagocytes (Petrovski et al., 2007) (Figure 4). Moreover, autophagy proteins themselves can exert proapoptotic functions. For example, Beclin-1 (Atg6), a key protein involved in autophagy, can interact with the antiapoptotic proteins Bcl-2 or Bcl-xL. This interaction is pro-apoptotic and antiautophagic, at least under non-autophagic stimuli. However, during autophagic conditions, Beclin-1 binding to Bcl-xL is antiapoptotic (Pattingre et al., 2005; Wang, 2008). In addition, Atg5 (when cleaved by activated calpain) can bind to Bcl-xL and induce apoptosis (Yousefi et al., 2006; Yousefi \& Simon, 2007). On the other hand, inactivation of autophagy genes (e.g. Atg5) also causes cell death (Komatsu et al., 2006), making matters even more complicated. These data demonstrate that the crosstalk between autophagy and apoptosis should not be neglected when designing interventions aimed at stabilizing atherosclerotic plaques via autophagy.

\subsubsection{Is autophagy an interesting drug target for plaque stabilization?}

Pharmacological modulation of autophagy can be achieved by targeting key players in the autophagy machinery (Rubinzstein et al., 2007). For example, rapamycin or its derivatives (e.g. everolimus) inhibit mTOR, thereby activating autophagy. Another way to modulate autophagy is to target the mTOR-independent route, mainly regulated by inositol-1,4,5triphosphate (IP3) levels. This can be achieved with drugs such as lithium, sodium valproate and carbamezapine. The first line of evidence that demonstrates the beneficial effects of autophagy induction in atherosclerosis was obtained after stent-based delivery of the rapamycin derivative everolimus in plaques of cholesterol-fed rabbits (Verheye et al., 2007). This treatment resulted in a marked reduction of macrophages via autophagic cell death without affecting the SMCs. However, recent in vitro work in our laboratory has demonstrated that pharmacological induction of autophagy in macrophages triggers secretion of proinflammatory cytokines such as IL-6, MCP1 and TNF $\alpha$ (Martinet, De Meyer, unpublished data), suggesting that the autophagic process is not immunologically silent. This cocktail of cytokines has the potential to induce SMC death and exacerbate the inflammatory infiltration of leukocytes in the plaque. Combined treatment with antiinflammatory agents such as glucocorticosteroids may help to prevent the adverse effects of drug-induced autophagy. On the other hand, induction of autophagy in free cholesterolloaded SMCs by rapamycin inhibited AC death (K. Xu et al., 2010), possibly through the degradation of dysfunctional organelles such as mitochondria and endoplasmic reticulum. These findings provide a rationale for the use of rapamycin or analogs such as everolimus to stabilize advanced atherosclerotic plaques.

Several studies have shed light on the potential detrimental consequences of autophagy inhibition with regard to plaque stability. Firstly, autophagy is essential for efficient phagocytosis of dying cells (Qu et al., 2007). ACs derived from cells lacking essential autophagy genes (Atg5 or beclin-1) fail to present the "eat-me" signal PS and secrete lower levels of the "come-get-me" signal lysophosphatidylcholine (Qu et al., 2007). This will result in a marked decrease in the engulfment of apoptotic corpses, enhanced plaque necrosis and recruitment of inflammatory cells (Gautier et al., 2009). Thus, inhibition of autophagy may further destabilize advanced plaques, where phagocytosis of ACs is already compromised (Schrijvers et al., 2005). Additionally, inhibition of autophagy using 3-methyladenine in free 
cholesterol-treated SMCs enhances apoptosis and necrosis (K. Xu et al., 2010), indicating that a strong interaction exists between autophagy and other forms of cell death (Maiuri et al., 2007). Of note, altering autophagy using pharmacological agents can be problematic, as they can interfere with general processes, such as glucose metabolism (e.g. metformin, deoxyglucose) or mitochondrial respiration (e.g. oligomycin). Broad-spectrum PI3 kinase inhibitors wortmannin and 3-methyladenine, widely used in autophagy research, inhibit Akt activation. Thus, results using these agents must always be interpreted carefully.

\section{Concluding remarks}

(Auto)phagocytosis plays a key role in maintaining atherosclerotic plaque stability (Figure 5). Efficient phagocytosis of AC is required to prevent accumulation of dead cells, expansion of the necrotic core in plaques and inflammatory responses resulting from secondary necrosis of residual AC. These factors will undoubtedly promote plaque inflammation, destabilization and rupture, leading to possible fatal ischemic events (e.g. myocardial infarction and stroke). Autophagy may be viewed as a "cry for survival," and such survival is the result of an adaptive response to fight against cellular stress. If this stress - such as oxidative damage in atherosclerotic plaques - is mild, autophagy is activated in order to

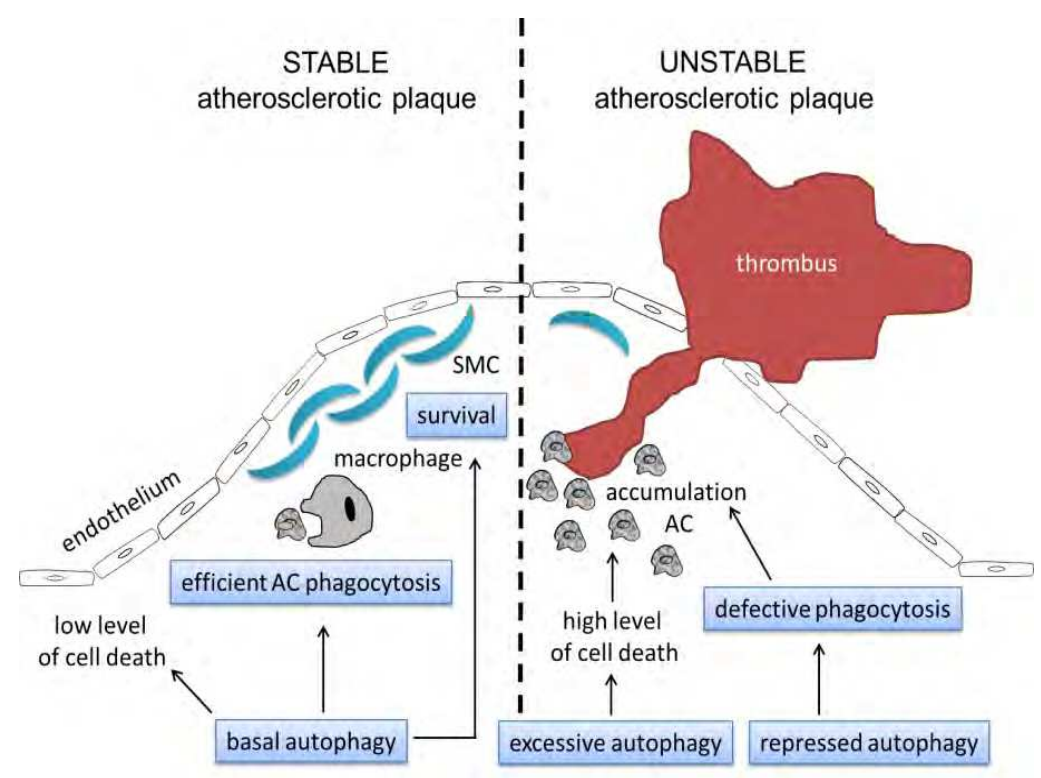

Fig. 5. Implications of dysfunctional phagocytosis and autophagy on the stability of atherosclerotic plaques. In stable plaques, AC numbers are low and phagocytosis is very efficient. Basal autophagy contributes to maintain efficient phagocytosis and promote cell survival. In unstable plaques, however, phagocytosis of AC is severely impaired, leading to accumulation of $\mathrm{AC}$, expansion of the necrotic core, thereby increasing the risk for plaque rupture, which results in the formation of an occlusive thrombus. Decreased autophagy probably worsens phagocytosis efficiency, which is already compromised in advanced plaques, whereas excessive autophagy can result in cell death and inflammatory responses. 
survive. On the other hand, if cellular stress is overwhelming or continuous, the adaptive response fails and cells undergo an autophagic type of death. Crossbreeding of mouse models for atherosclerosis (e.g. ApoE or LDL receptor knockout animals) with autophagydeficient mice (e.g. conditional Atg5 or Atg7 knockout animals) will undoubtedly shed more light on the potential role of autophagy in atherosclerosis. Based on the literature and promising experiments in our lab and that of others, it is definite that cells need autophagy to be able to survive under stressful circumstances. Therefore, controlled (moderate) induction of autophagy, but not excessive induction or inhibition of autophagy, seems to be a promising strategy for stabilization of atherosclerotic plaques. The challenge for the future in the stabilization of atherosclerotic plaques will be to turn on the protective pro-survival effects of autophagy in a selective manner, without activating unwanted death pathways or proinflammatory signaling cascades. With progress being made in tissue-specific drug targeting using nanoparticles, one potential future approach to stabilize atherosclerotic plaques would be to develop macrophage-specific phagocytosis and/or autophagy inducers combined with anti-inflammatory drugs. However, stimulation of autophagy can only be beneficial if autophagic flux is not impaired, since this condition could lead to lysosomal leakage or ejection of autophagosomes as well as the induction of cell death. Altogether, (auto)phagocytosis is a crucial process involved in atherogenesis that significantly affects the stability of the atherosclerotic plaque.

\section{Acknowledgements}

This work was supported by the Fund for Scientific Research-Flanders and the University of Antwerp.

\section{References}

A-Gonzalez, N., Bensinger, S.J., Hong, C., Beceiro, S., Bradley, M.N., Zelcer, N., Deniz, J., Ramirez, C., Díaz, M., Gallardo, G., de Galarreta, C.R., Salazar, J., Lopez, F., Edwards, P., Parks, J., Andujar, M., Tontonoz, P. \& Castrillo, A. (2009) Apoptotic cells promote their own clearance and immune tolerance through activation of the nuclear receptor LXR. Immunity,31,2,pp.245-58.

Ait-Oufella, H., Kinugawa, K., Zoll, J., Simon, T., Boddaert, J., Heeneman, S., Blanc-Brude, O., Barateau, V., Potteaux, S., Merval, R., Esposito, B., Teissier, E., Daemen, M.J., Lesèche, G., Boulanger, C., Tedgui, A. \& Mallat, Z. (2007) Lactadherin deficiency leads to apoptotic cell accumulation and accelerated atherosclerosis in mice. Circulation,115,16,pp.2168-77.

Ait-Oufella, H., Pouresmail, V., Simon, T., Blanc-Brude, O., Kinugawa, K., Merval, R., Offenstadt, G., Lesèche, G., Cohen, P.L., Tedgui, A. \& Mallat, Z. (2008) Defective mer receptor tyrosine kinase signaling in bone marrow cells promotes apoptotic cell accumulation and accelerates atherosclerosis. Arterioscler Thromb Vasc Biol,28,8, pp.1429-31.

Andersson, U., Wang, H., Palmblad, K., Aveberger, A.C., Bloom, O., Erlandsson-Harris, H., Janson, A., Kokkola, R., Zhang, M., Yang, H. \& Tracey, K.J. (2000) High mobility group 1 protein (HMG-1) stimulates proinflammatory cytokine synthesis in human monocytes. J Exp Med,192,4,pp. 565-70. 
Arur, S., Uche, U.E., Rezaul, K., Fong, M., Scranton, V., Cowan, A.E., Mohler, W. \& Han, D.K. (2003) Annexin I is an endogenous ligand that mediates apoptotic cell engulfment. Dev Cell,4,4,pp.587-98.

Azad, M.B., Chen, Y., Henson, E.S., Cizeau, J., McMillan-Ward, E., Israels, S.J. \& Gibson, S.B. (2008) Hypoxia induces autophagic cell death in apoptosis-competent cells through a mechanism involving BNIP3. Autophagy,4,2,pp.195-204.

Basu, S., Binder, R.J., Suto, R., Anderson, K.M. \& Srivastava, P.K. (2000) Necrotic but not apoptotic cell death releases heat shock proteins, which deliver a partial maturation signal to dendritic cells and activate the NF-kappa B pathway. Int Immunol, 12,11,pp.1539-46.

Behrensdorf, H.A., van de Craen, M., Knies, U.E., Vandenabeele, P. \& Clauss, M. (2000) The endothelial monocyte-activating polypeptide II (EMAP II) is a substrate for caspase-7. FEBS Lett,466,1,pp.143-7.

Benati, D., Ferro, M., Savino, M.T., Ulivieri, C., Schiavo, E., Nuccitelli, A., Pasini, F.L. \& Baldari, C.T. (2010) Opposite effects of simvastatin on the bactericidal and inflammatory response of macrophages to opsonized S. aureus. J Leukoc Biol, 87,3,pp.433-42.

Bhatia, V.K., Yun, S., Leung,V., Grimsditch, D.C., Benson, G.M., Botto, M.B., Boyle, J.J. \& Haskard, D.O. (2007) Complement C1q reduces early atherosclerosis in low-density lipoprotein receptor-deficient mice. Am J Pathol,170,1,pp. 416-23.

Boisvert, W.A., Rose, D.M., Boullier, A., Quehenberger, O., Sydlaske, A., Johnson, K.A., Curtiss, L.K. \& Terkeltaub, R. (2006) Leukocyte transglutaminase 2 expression limits atherosclerotic lesion size. Arterioscler Thromb Vasc Biol,26,3,pp.563-9.

Bouhlel, M.A., Derudas, B., Rigamonti, E., Dièvart, R., Brozek, J., Haulon, S., Zawadzki, C., Jude, B., Torpier, G., Marx, N., Staels, B. \& Chinetti-Gbaguidi, G. (2007) PPARgamma activation primes human monocytes into alternative M2 macrophages with anti-inflammatory properties. Cell Metab,6,2,pp.137-43.

Brown, S., Heinisch, I., Ross, E., Shaw, K., Buckley, C.D. \& Savill, J. (2002) Apoptosis disables CD31-mediated cell detachment from phagocytes promoting binding and engulfment. Nature,418,6894,pp.200-3.

Callahan, M.K., Williamson, P. \& Schlegel, R.A. (2000) Surface expression of phosphatidylserine on macrophages is required for phagocytosis of apoptotic thymocytes. Cell Death Differ,7,7,pp.645-53.

Cash, J.L., Christian, A.R. \& Greaves, D.R. (2010) Chemerin peptides promote phagocytosis in a ChemR23- and Syk-dependent manner. J Immunol,184,9,pp.5315-24.

Cui, D., Thorp, E., Li, Y., Wang, N., Yvan-Charvet, L., Tall, A.R. \& Tabas, I. (2007) Pivotal advance: macrophages become resistant to cholesterol-induced death after phagocytosis of apoptotic cells. J Leukoc Biol,82,5,pp.1040-50.

Devitt, A., Moffatt, O.D., Raykundalia, C., Capra, J.D., Simmons, D.L. \& Gregory, C.D. (1998) Human CD14 mediates recognition and phagocytosis of apoptotic cells. Nature,392,6675,pp.505-9.

Devitt, A. \& Marshall, L.J. (2011) The innate immune system and the clearance of apoptotic cells. J Leukoc Biol. May 11. [Epub ahead of print]

Dice, J.F. (2007) Chaperone-mediated autophagy. Autophagy,3,4,pp.295-9.

Donato, R. (2003) Intracellular and extracellular roles of S100 proteins. Microsc Res Tech, 60,6,pp.540-51. 
Elliott, M.R., Chekeni, F.B., Trampont, P.C., Lazarowski, E.R., Kadl, A., Walk, S.F., Park, D., Woodson, R.I., Ostankovich, M., Sharma, P., Lysiak, J.J., Harden, T.K., Leitinger, N. \& Ravichandran, K.S. (2009) Nucleotides released by apoptotic cells act as a findme signal to promote phagocytic clearance. Nature,461,7261,pp.282-6.

Elliott, M.R. \& Ravichandran K.S. (2010) Clearance of apoptotic cells: implications in health and disease. J Cell Biol,189,pp.1059-70.

Erwig, L.P.\& Henson, P.M. (2007) Immunological consequences of apoptotic cell phagocytosis. Am J Pathol,171,1,pp.2-8.

Fadok, V.A., Voelker, D.R., Campbell, P.A., Cohen, J.J., Bratton, D.L. \& Henson, P.M. (1992) Exposure of phosphatidylserine on the surface of apoptotic lymphocytes triggers specific recognition and removal by macrophages. J Immunol,148,7,pp.2207-16.

Fadok, V.A., Bratton, D.L., Konowal, A., Freed, P.W., Westcott, J.Y. \& Henson, P.M. (1998) Macrophages that have ingested apoptotic cells in vitro inhibit proinflammatory cytokine production through autocrine/paracrine mechanisms involving TGF-beta, PGE2, and PAF. J Clin Invest,101,4,pp.890-8.

Foell, D., Frosch, M., Sorg, C. \& Roth, J. (2004) Phagocyte-specific calcium-binding S100 proteins as clinical laboratory markers of inflammation. Clin Chim Acta,344,1,pp.3751.

Foell, D., Wittkowski, H., Ren, Z., Turton, J., Pang, G., Daebritz, J., Ehrchen, J., Heidemann. J., Borody, T., Roth, J. \& Clancy, R. (2008) Phagocyte-specific S100 proteins are released from affected mucosa and promote immune responses during inflammatory bowel disease. J Pathol,216,2,pp.183-92.

Gaipl, U.S., Kuenkele, S., Voll, R.E., Beyer, T.D., Kolowos, W., Heyder, P., Kalden, J.R. \& Herrmann, M. (2001) Complement binding is an early feature of necrotic and a rather late event during apoptotic cell death. Cell Death Differ,8,4,pp.327-34.

Gardai, S.J., McPhillips, K.A., Frasch, S.C., Janssen, W.J., Starefeldt, A., Murphy-Ullrich, J.E., Bratton, D.L., Oldenborg, P.A., Michalak, M. \& Henson, P.M. (2005) Cell-surface calreticulin initiates clearance of viable or apoptotic cells through trans-activation of LRP on the phagocyte. Cell,123,2,pp.321-34.

Gautier, E.L., Huby, T., Witztum, J.L., Ouzilleau, B., Miller, E.R., Saint-Charles, F., Aucouturier, P., Chapman, M.J. \& Lesnik, P. (2009) Macrophage apoptosis exerts divergent effects on atherogenesis as a function of lesion stage. Circulation,119, pp.1795-1804.

Getz, G.S. \& Reardon, C.A. (2006) Diet and murine atherosclerosis. Arterioscler Thromb Vasc Biol,26,2,pp.242-9.

Ghaemi-Oskouie, F. \& Shi, Y. (2011) The role of uric acid as an endogenous danger signal in immunity and inflammation. Curr Rheumatol Rep,13,2,pp.160-6.

Godson, C., Mitchell, S., Harvey, K., Petasis, N.A., Hogg, N. \& Brady, H.R. (2000) Cutting edge: lipoxins rapidly stimulate nonphlogistic phagocytosis of apoptotic neutrophils by monocyte-derived macrophages. J Immunol,164,4,pp.1663-7.

Golpon, H.A., Fadok, V.A., Taraseviciene-Stewart, L., Scerbavicius, R., Sauer, C., Welte, T., Henson, P.M. \& Voelkel, N.F. (2004) Life after corpse engulfment: phagocytosis of apoptotic cells leads to VEGF secretion and cell growth. FASEB J,18,pp.1716-1718.

Gottlieb, R.A. \& Mentzer, R.M. (2010) Autophagy during cardiac stress: joys and frustrations of autophagy. Annu Rev Physiol,72,pp.45-59. 
Gozuacik, D. \& Kimchi, A. (2004) Autophagy as a cell death and tumor suppressor mechanism. Oncogene,23,pp.2891-2906.

Green, D.R., Ferguson, T., Zitvogel, L. \& Kroemer, G. (2009) Immunogenic and tolerogenic cell death. Nat Rev Immunol,9,pp.353-363.

Grimsley, C. \& Ravichandran, K.S. (2003) Cues for apoptotic cell engulfment: eat-me, don't eat-me and come-get-me signals. Trends Cell Biol,13,pp.648-656.

Gude, D.R., Alvarez, S.E., Paugh, S.W., Mitra, P., Yu, J., Griffiths, R., Barbour, S.E., Milstien, S.\& Spiegel, S. (2008) Apoptosis induces expression of sphingosine kinase 1 to release sphingosine-1-phosphate as a "come-and-get-me" signal. FASEB J, 22,8,pp.2629-38.

Hansson, G.K. (2005) Inflammation, atherosclerosis, and coronary artery disease. N Engl J Med,352,16,pp.1685-95.

Hart, S.P., Alexander, K.M., MacCall, S.M. \& Dransfield, I. (2005) C-reactive protein does not opsonize early apoptotic human neutrophils, but binds only membrane-permeable late apoptotic cells and has no effect on their phagocytosis by macrophages. J Inflamm (Lond),31,pp.2-5.

Henson, P.M., Bratton, D.L. \& Fadok, V.A. (2001) Apoptotic cell removal. Curr Biol, 11,19,pp.R795-805.

Heymann, D. (2006) Autophagy: a protective mechanism in response to stress and inflammation. Curr Opin Investig Drugs,7,pp.443-450.

Hirt, U.A. \& Leist, M. (2003) Rapid, noninflammatory and PS-dependent phagocytic clearance of necrotic cells. Cell Death Differ,10,10,pp.1156-64.

Hodge, S., Hodge, G., Brozyna, S., Jersmann, H., Holmes, M. \& Reynolds, P.N. (2006) Azithromycin increases phagocytosis of apoptotic bronchial epithelial cells by alveolar macrophages. Eur Respir J,28,3,pp.486-95.

Hoffmann, P.R., deCathelineau, A.M., Ogden, C.A., Leverrier, Y., Bratton, D.L., Daleke, D.L., Ridley, A.J., Fadok, V.A. \& Henson, P.M. (2001) Phosphatidylserine (PS) induces PS receptor-mediated macropinocytosis and promotes clearance of apoptotic cells. $J$ Cell Biol,155,4,pp.649-59.

Horino, K., Nishiura, H., Ohsako, T., Shibuya, Y., Hiraoka, T., Kitamura, N. \& Yamamoto, T. (1998) A monocyte chemotactic factor, S19 ribosomal protein dimer, in phagocytic clearance of apoptotic cells. Lab Invest,78,5,pp.603-17.

Hou, Y., Plett, P.A., Ingram, D.A., Rajashekhar, G., Orschell, C.M., Yoder, M.C., March, K.L. \& Clauss, M. (2006) Endothelial-monocyte-activating polypeptide II induces migration of endothelial progenitor cells via the chemokine receptor CXCR3. Exp Hematol,34,8,pp.1125-32.

Hugel, B., Martínez, M.C., Kunzelmann, C. \& Freyssinet, J.M. (2005) Membrane microparticles: two sides of the coin. Physiology (Bethesda),20,pp.22-7.

Jehle, A.W., Gardai, S.J., Li, S., Linsel-Nitschke, P., Morimoto, K., Janssen, W.J., Vandivier, R.W., Wang, N., Greenberg, S., Dale, B.M., Qin, C., Henson, P.M. \& Tall, A.R. (2006) ATP-binding cassette transporter A7 enhances phagocytosis of apoptotic cells and associated ERK signaling in macrophages. J Cell Biol,174,4,pp.547-56.

Jia, G., Cheng, G., Gangahar, D.M. \& Agrawal, D.K. (2006) Insulin-like growth factor-1 and TNF-alpha regulate autophagy through c-jun N-terminal kinase and Akt pathways in human atherosclerotic vascular smooth cells. Immunol Cell Biol,84,pp.448-454. 
Kannel,. W.B., D'Agostino, R.B., Sullivan, L. \& Wilson, P.W. (2004) Concept and usefulness of cardiovascular risk profiles. Am Heart J,148,1,pp.16-26.

Kiffin, R., Bandyopadhyay, U. \& Cuervo, A.M. (2006) Oxidative stress and autophagy. Antioxid Redox Signal,8,pp.152-62.

Kimura, S., Noda, T. \& Yoshimori, T. (2007) Dissection of the autophagosome maturation process by a novel reporter protein, tandem fluorescent-tagged LC3. Autophagy, 3,pp.452-60.

Kinchen, J.M. (2010) A model to die for: signaling to apoptotic cell removal in worm, fly and mouse. Apoptosis,15,998-1006.

Kiss, R.S., Elliott, M.R., Ma, Z., Marcel, Y.L. \& Ravichandran, K.S. (2006) Apoptotic cells induce a phosphatidylserine-dependent homeostatic response from phagocytes. Curr Biol. 16,22,pp.2252-8.

Klionsky, D.J. (2007) Autophagy: from phenomenology to molecular understanding in less than a decade. Nat Rev Mol Cell Biol,8,11,pp.931-7.

Klionsky, D.J., Cuervo, A.M., Dunn, W.A. Jr, Levine, B., van der Klei, I. \& Seglen, P.O. (2007) How shall I eat thee? Autophagy,3,5,pp.413-6.

Knies, U.E., Behrensdorf, H.A., Mitchell, C.A., Deutsch, U., Risau, W., Drexler, H.C. \& Clauss, M. (1998) Regulation of endothelial monocyte-activating polypeptide II release by apoptosis. Proc Natl Acad Sci U S A,95,21,pp.12322-7.

Komatsu, M., Waguri, S., Chiba, T., Murata, S., Iwata, J., Tanida, I., Ueno, T., Koike, M., Uchiyama, Y., Kominami, E. \& Tanaka, K. (2006) Loss of autophagy in the central nervous system causes neurodegeneration in mice. Nature,441,pp.880-884.

Krysko, D.V., D'Herde, K. \& Vandenabeele, P. (2006) Clearance of apoptotic and necrotic cells and its immunological consequences. Apoptosis,11,10,pp.1709-26.

Lauber, K., Bohn, E., Krober, S.M., Xiao, Y.J., Blumenthal, S.G., Lindemann, R.K., Marini, P., Wiedig, C., Zobywalski, A., Baksh, S., Xu, Y., Autenrieth, I.B., Schulze-Osthoff, K., Belka, C., Stuhler, G. \& Wesselborg, S. (2003) Apoptotic cells induce migration of phagocytes via caspase-3-mediated release of a lipid attraction signal. Cell,113,6, pp.717-730.

Le, L.Q., Kabarowski, J.H., Weng, Z., Satterthwaite, A.B., Harvill, E.T., Jensen, E.R., Miller, J.F. \& Witte, O.N. (2001) Mice lacking the orphan G protein-coupled receptor G2A develop a late-onset autoimmune syndrome. Immunity,14,5,pp.561-71.

Levine, B. \& Yuan, J. (2005) Autophagy in cell death: an innocent convict? J Clin Invest, $115, p p .2679-88$.

Levine, B. \& Kroemer, G. (2008) Autophagy in the pathogenesis of disease. Cell,132,pp.27-42.

Li, M., Carpio, D.F., Zheng, Y., Bruzzo, P., Singh, V., Ouaaz, F., Medzhitov, R.M. \& Beg, A.A. (2001) An essential role of the NF-kappa B/Toll-like receptor pathway in induction of inflammatory and tissue-repair gene expression by necrotic cells. J Immunol, 166,12,pp.7128-35.

Li, S., Sun, Y., Liang, C.P., Thorp, E.B., Han, S., Jehle, A.W., Saraswathi, V., Pridgen, B., Kanter, J.E., Li, R., Welch, C.L., Hasty, A.H., Bornfeldt, K.E., Breslow, J.L., Tabas, I. \& Tall, AR. (2009) Defective phagocytosis of apoptotic cells by macrophages in atherosclerotic lesions of ob/ob mice and reversal by a fish oil diet. Circ Res,105,11,pp.1072-82. 
Lillis, A.P., Van Duyn, L.B., Murphy-Ullrich, J.E. \& Strickland, D.K. (2008) LDL receptorrelated protein 1: unique tissue-specific functions revealed by selective gene knockout studies. Physiol Rev,88,3,pp.887-918.

Maiuri, M.C., Zalckvar, E., Kimchi, A. \& Kroemer, G. (2007) Self-eating and self-killing: crosstalk between autophagy and apoptosis. Nat Rev Mol Cell Biol,8,pp.741-52.

Mathew, R., Karantza-Wadsworth, V. \& White, E. (2007) Role of autophagy in cancer. Nat Rev Cancer,7,pp.961-7.

Martinet, W., Verheye, S. \& De Meyer, G.R.Y. (2007) Selective depletion of macrophages in atherosclerotic plaques via macrophage-specific initiation of cell death. Trends Cardiovasc Med,17,pp.69-75.

Martinet, W. \& De Meyer G.R.Y. (2008) Autophagy in atherosclerosis. Curr Atheroscler Rep,10,3,pp.216-23.

Martinet, W., Schrijvers D,M., Timmermans, J.P. \& Bult, H. (2008) Interactions between cell death induced by statins and 7-ketocholesterol in rabbit aorta smooth muscle cells. Br J Pharmacol,154,pp.1236-46.

Martinet, W. \& De Meyer, G.R.Y. (2009a) Autophagy in the cardiovascular system. Biochim Biophys Acta,1793,pp.1485-95.

Martinet, W. \& De Meyer, G.R.Y. (2009b) Autophagy in atherosclerosis: a cell survival and death phenomenon with therapeutic potential. Circ Res,104,3,pp.304-17.

Martinet, W., De Meyer, I., Cools, N., Timmerman, V., Bult, H., Bosmans, J. \& De Meyer G.R.Y. (2010) Cell death-mediated cleavage of the attraction signal p43 in human atherosclerosis: implications for plaque destabilization. Arterioscler Thromb Vasc Biol,30,7,pp.1415-22.

Martins, I., Kepp, O., Galluzzi, L., Senovilla, L., Schlemmer, F., Adjemian, S., Menger, L., Michaud, M., Zitvogel, L. \& Kroemer, G. (2010) Surface-exposed calreticulin in the interaction between dying cells and phagocytes. Ann N Y Acad Sci,1209,pp.77-82.

Miyanishi, M., Tada, K., Koike, M., Uchiyama, Y., Kitamura, T. \& Nagata, S. (2007) Identification of Tim4 as a phosphatidylserine receptor. Nature, 450,7168,pp.435-9.

Mizushima, N., Levine, B., Cuervo, A.M. \& Klionsky, D.J. (2008) Autophagy fights disease through cellular self-digestion. Nature,45,pp.1069-75.

Mizushima, N., Yoshimori, T. \& Levine, B. (2010) Methods in mammalian autophagy research. Cell,140,pp.313-26.

Möller, W., Hofer, T., Ziesenis, A., Karg, E. \& Heyder, J. (2002) Ultrafine particles cause cytoskeletal dysfunctions in macrophages. Toxicol Appl Pharmacol,182,3,pp.197-207.

Morimoto, K., Janssen, W.J., Fessler, M.B., McPhillips, K.A., Borges, V.M., Bowler, R.P., Xiao, Y.Q., Kench, J.A., Henson, P.M. \& Vandivier, R.W. (2006) Lovastatin enhances clearance of apoptotic cells (efferocytosis) with implications for chronic obstructive pulmonary disease. J Immunol,176,12,pp.7657-65.

Moura, R., Tjwa, M., Vandervoort, P., Van Kerckhoven, S., Holvoet, P. \& Hoylaerts, M.F. (2008) Thrombospondin-1 deficiency accelerates atherosclerotic plaque maturation in ApoE-/- mice. Circ Res,103,10,pp.1181-9.

Mukundan, L., Odegaard, J.I., Morel, C.R., Heredia, J.E., Mwangi, J.W., Ricardo-Gonzalez, R.R., Goh, Y.P., Eagle, A.R., Dunn, S.E., Awakuni, J.U., Nguyen, K.D., Steinman, L., Michie, S.A. \& Chawla, A. (2009) PPAR-delta senses and orchestrates clearance of apoptotic cells to promote tolerance. Nat Med,15,11,pp.1266-72. 
Muller, M., Salvayre, R., Negre-Salvayre, A. \& Vindis, C. (2011) Oxidized LDLs trigger endoplasmic reticulum stress and autophagy: Prevention by HDLs. Autophagy, 7,pp.541-543.

Nakamura, H., Izumoto, Y., Kambe, H., Kuroda, T., Mori, T., Kawamura, K., Yamamoto, H. \& Kishimoto, T. (1994) Molecular cloning of complementary DNA for a novel human hepatoma-derived growth factor. Its homology with high mobility group-1 protein. J Biol Chem,269,40,pp.25143-9.

Nauta, A.J., Raaschou-Jensen, N., Roos, A., Daha, M.R., Madsen, H.O., Borrias-Essers, M.C., Ryder, L.P., Koch, C. \& Garred, P. (2003) Mannose-binding lectin engagement with late apoptotic and necrotic cells. Eur J Immunol,33,10,pp.2853-63.

Nishiura, H., Shibuya, Y., Matsubara, S., Tanase, S., Kambara, T. \& Yamamoto, T. (1996) Monocyte chemotactic factor in rheumatoid arthritis synovial tissue. Probably a cross-linked derivative of S19 ribosomal protein. J Biol Chem,271,2,pp.878-82.

Nowicki, M., Zabirnyk, O., Duerrschmidt, N., Borlak, J. \& Spanel-Borowski, K. (2007) No upregulation of lectin-like oxidized low-density lipoprotein receptor-1 in serumdeprived EA.hy926 endothelial cells under oxLDL exposure, but increase in autophagy. Eur J Cell Biol,86,pp.605-16.

Ogden, C.A., deCathelineau, A., Hoffmann, P.R., Bratton, D., Ghebrehiwet, B., Fadok, V.A. \& Henson, P.M. (2001) C1q and mannose binding lectin engagement of cell surface calreticulin and CD91 initiates macropinocytosis and uptake of apoptotic cells. J Exp Med,194,6,pp.781-95.

Park, D., Tosello-Trampont, A.C., Elliott, M.R., Lu, M., Haney, L.B., Ma, Z., Klibanov, A.L., Mandell, J.W. \& Ravichandran, K.S. (2007) BAI1 is an engulfment receptor for apoptotic cells upstream of the ELMO/Dock180/Rac module. Nature, 450,7168,pp.430-4.

Park, S.Y., Jung, M.Y., Kim, H.J., Lee, S.J., Kim, S.Y., Lee, B.H., Kwon, T.H., Park, R.W. \& Kim, I.S. (2008) Rapid cell corpse clearance by stabilin-2, a membrane phosphatidylserine receptor. Cell Death Differ,15,1,pp.192-201.

Patel, V.A., Longacre, A., Hsiao, K., Fan, H., Meng, F., Mitchell, J.E., Rauch, J., Ucker, D.S. \& Levine, J.S. (2006) Apoptotic cells, at all stages of the death process, trigger characteristic signaling events that are divergent from and dominant over those triggered by necrotic cells: Implications for the delayed clearance model of autoimmunity. J Biol Chem,281,8,pp.4663-70.

Pattingre, S., Tassa, A., Qu, X., Garuti, R., Liang, X.H., Mizushima, N., Packer, M., Schneider, M.D. \& Levine, B. (2005) Bcl-2 antiapoptotic proteins inhibit Beclin 1-dependent autophagy. Cell,122,pp.927-39.

Peng, Y., Latchman, Y. \& Elkon, KB. (2009) Ly6C(low) monocytes differentiate into dendritic cells and cross-tolerize T cells through PDL-1. J Immunol,182,5,pp.2777-85.

Peter, C., Waibe, M., Radu, C.G., Yang, L.V., Witte, O.N., Schulze-Osthoff, K., Wesselborg, S. \& Lauber, K. (2008) Migration to apoptotic "find-me" signals is mediated via the phagocyte receptor G2A. J Biol Chem,283,9,pp.5296-305.

Peter, C., Wesselborg, S., Herrmann, M. \& Lauber, K. (2010) Dangerous attraction: phagocyte recruitment and danger signals of apoptotic and necrotic cells. Apoptosis, 15,9,pp.1007-28. 
Petrovski, G., Zahuczky, G., Májai, G. \& Fésüs, L. (2007) Phagocytosis of cells dying through autophagy evokes a proinflammatory response in macrophages. Autophagy, 3,5,pp.509-11.

Poon, I.K., Hulett, M.D. \& Parish, C.R. (2010) Molecular mechanisms of late apoptotic/necrotic cell clearance. Cell Death Differ,17,3,pp.381-97.

Pradhan, D., Krahling, S., Williamson, P. \& Schlegel, R.A. (1997) Multiple systems for recognition of apoptotic lymphocytes by macrophages. Mol Biol Cell,8,5,pp.767-78.

Qin, L., Wang, Z., Tao, L. \& Wang, Y. (2010) ER stress negatively regulates AKT/TSC/mTOR pathway to enhance autophagy. Autophagy,6,pp.239-247.

Qingxian L, Qiutang L, Qingjun L. (2010) Regulation of phagocytosis by TAM receptors and their ligands. Front Biol,5,3,pp.227-37.

Qu, X., Zou, Z., Sun, Q., Luby-Phelps, K., Cheng, P., Hogan, R.N., Gilpin, C. \& Levine, B. (2007) Autophagy gene-dependent clearance of apoptotic cells during embryonic development. Cell,128,pp.931-46.

Ravikumar, B., Sarkar, S., Davies, J.E., Futter, M., Garcia-Arencibia, M., Green-Thompson, Z.W., Jimenez-Sanchez, M., Korolchuk, V.I., Lichtenberg, M., Luo, S., Massey, D.C., Menzies, F.M., Moreau, K., Narayanan, U., Renna, M., Siddiqi, F.H., Underwood, B.R., Winslow, A.R. \& Rubinsztein, D.C. (2010) Regulation of mammalian autophagy in physiology and pathophysiology. Physiol Rev,90,pp.1383-435.

Reddy, S.M., Hsiao, K.H., Abernethy, V.E., Fan, H., Longacre, A., Lieberthal, W., Rauch, J., Koh, J.S. \& Levine, J.S. (2002) Phagocytosis of apoptotic cells by macrophages induces novel signaling events leading to cytokine-independent survival and inhibition of proliferation: activation of Akt and inhibition of extracellular signalregulated kinases 1 and 2. J Immunol,169,2,pp.702-13.

Rovere, P., Peri, G., Fazzini, F., Bottazzi, B., Doni, A., Bondanza, A., Zimmermann, V.S., Garlanda, C., Fascio, U., Sabbadini, M.G., Rugarli, C., Mantovani, A. \& Manfredi, A.A. (2000) The long pentraxin PTX3 binds to apoptotic cells and regulates their clearance by antigen-presenting dendritic cells. Blood,96,13,pp.4300-6.

Rubinsztein, D.C., Gestwicki, J.E., Murphy, L.O. \& Klionsky, D.J. (2007) Potential therapeutic applications of autophagy. Nat Rev Drug Discov,6,pp.304-12.

Sambrano, G.R. \& Steinberg, D. (1995) Recognition of oxidatively damaged and apoptotic cells by an oxidized low density lipoprotein receptor on mouse peritoneal macrophages: role of membrane phosphatidylserine. Proc Natl Acad Sci U $S$ A, 92,pp.1396-400.

Sather, S., Kenyon, K.D., Lefkowitz, J.B., Liang, X., Varnum, B.C., Henson, P.M. \& Graham, D.K. (2007) A soluble form of the Mer receptor tyrosine kinase inhibits macrophage clearance of apoptotic cells and platelet aggregation. Blood,109,3,pp.1026-33.

Savill, J., Hogg, N., Ren, Y. \& Haslett, C. (1992) Thrombospondin cooperates with CD36 and the vitronectin receptor in macrophage recognition of neutrophils undergoing apoptosis. J Clin Invest,90,4,pp.1513-22.

Scaffidi, P., Misteli, T. \& Bianchi, M.E. (2002) Release of chromatin protein HMGB1 by necrotic cells triggers inflammation. Nature,418,6894,pp.191-5.

Scannell, M., Flanagan, M.B., deStefani, A., Wynne, K.J., Cagney, G., Godson, C. \& Maderna, P. (2007) Annexin-1 and peptide derivatives are released by apoptotic cells and stimulate phagocytosis of apoptotic neutrophils by macrophages. J Immunol,178,7, pp.4595-605. 
Scherz-Shouval, R. \& Elazar, Z. (2011) Regulation of autophagy by ROS: physiology and pathology. Trends Biochem Sci,36,pp.30-38.

Schlegel, R.A., Krahling, S., Callahan, M.K. \& Williamson, P. (1999) CD14 is a component of multiple recognition systems used by macrophages to phagocytose apoptotic lymphocytes. Cell Death Differ,6,6,pp.583-92.

Schrijvers, D.M., De Meyer, G.R., Kockx, M.M., Herman, A.G. \& Martinet, W. (2005) Phagocytosis of apoptotic cells by macrophages is impaired in atherosclerosis. Arterioscl Thromb Vasc Biol,25,6,pp.1256-61.

Schrijvers, D.M., De Meyer, G.R.Y., Herman, A.G. \& Martinet, W. (2007) Phagocytosis in atherosclerosis: Molecular mechanisms and implications for plaque progression and stability. Cardiovasc Res,73,3,pp.470-80.

Segundo, C., Medina, F., Rodríguez, C., Martínez-Palencia, R., Leyva-Cobián, F.\& Brieva, J.A. (1999) Surface molecule loss and bleb formation by human germinal center B cells undergoing apoptosis: role of apoptotic blebs in monocyte chemotaxis. Blood, 94,3,pp.1012-20.

Serhan, C.N., Chiang, N. \& Van Dyke, T.E. (2008) Resolving inflammation: dual antiinflammatory and pro-resolution lipid mediators. Nat Rev Immunol,8,5,pp.349-61.

Shi, Y., Evans, J.E. \& Rock, K.L. (2003) Molecular identification of a danger signal that alerts the immune system to dying cells. Nature,425,6957,pp.516-21.

Shimada, K. (2009) Immune system and atherosclerotic disease: heterogeneity of leukocyte subsets participating in the pathogenesis of atherosclerosis. Circ J,73,6,pp.994-1001.

Shintani, T. \& Klionsky, D.J. (2004) Autophagy in health and disease: a double-edged sword. Science,306,pp.990-5.

Simons, M. \& Raposo, G. (2009) Exosomes-vesicular carriers for intercellular communication. Curr Opin Cell Biol,21,pp.575-81.

Sindrilaru, A., Peters, T., Schymeinsky, J., Oreshkova, T., Wang, H., Gompf, A., Mannella, F., Wlaschek, M., Sunderkötter, C., Rudolph, K.L., Walzog, B., Bustelo, X.R., Fischer, K.D. \& Scharffetter-Kochanek, K. (2009) Wound healing defect of Vav3-/- mice due to impaired \{beta\}2-integrin-dependent macrophage phagocytosis of apoptotic neutrophils. Blood,113,21,pp.5266-76.

Sluimer, J.C., Gasc, J.M., van Wanroij, J.L., Kisters, N., Groeneweg, M., Sollewijn, G., Cleutjens, J.P., van den Akker, L.H., Corvol, P., Wouters, B.G., Daemen, M.J. \& Bijnens, A.P. (2008) Hypoxia, hypoxia-inducible transcription factor, and macrophages in human atherosclerotic plaques are correlated with intraplaque angiogenesis. J Am Coll Cardiol,51,pp.1258-65.

Su, Y.R., Dove, D.E., Major, A.S., Hasty, A.H., Boone, B., Linton, M.F. \& Fazio, S. (2005) Reduced ABCA1-mediated cholesterol efflux and accelerated atherosclerosis in apolipoprotein E-deficient mice lacking macrophage-derived ACAT1. Circulation, 111,18,pp.2373-81.

Szondy, Z., Sarang, Z., Molnar, P., Nemeth, T., Piacentini, M., Mastroberardino, P.G., Falasca, L., Aeschlimann, D., Kovacs, J., Kiss, I., Szegezdi, E., Lakos, G., Rajnavolgyi, E., Birckbichler, P.J., Melino, G. \& Fesus, L. (2003) Transglutaminase 2 -/- mice reveal a phagocytosis-associated crosstalk between macrophages and apoptotic cells. Proc Natl Acad Sci U S A,100,13,pp.7812-7. 
Tabas, I. (2005) Consequences and therapeutic implications of macrophage apoptosis in atherosclerosis: the importance of lesion stage and phagocytic efficiency. Arterioscler Thromb Vasc Biol,25,11,pp.2255-64.

Tabas, I. (2010) Macrophage death and defective inflammation resolution in atherosclerosis. Nat Rev Immunol,10,1,pp.36-46.

Tang, D., Kang, R., Xiao, W., Wang, H., Calderwood, S.K. \& Xiao, X. (2007) The antiinflammatory effects of heat shock protein 72 involve inhibition of high-mobilitygroup box 1 release and proinflammatory function in macrophages. J Immunol, 179,2,pp.1236-44.

Tedgui, A. \& Mallat, Z. (2001) Apoptosis as a determinant of atherothrombosis. Thromb Haemost, 86,1,pp.420-6.

Thorp, E., Cui, D., Schrijvers, D.M., Kuriakose, G. \& Tabas, I. (2008) Mertk receptor mutation reduces efferocytosis efficiency and promotes apoptotic cell accumulation and plaque necrosis in atherosclerotic lesions of apoe-/- mice. Arterioscler Thromb Vasc Biol,28,8,pp.1421-8.

Thorp, E. \& Tabas, I. (2009) Mechanisms and consequences of efferocytosis in advanced atherosclerosis. J Leukoc Biol,86,5,pp.1089-95.

Thorp, E.B. (2010) Mechanisms of failed apoptotic cell clearance by phagocyte subsets in cardiovascular disease. Apoptosis,15,pp.1124-36.

Truman, L.A., Ford, C.A., Pasikowska, M., Pound, J.D., Wilkinson, S.J., Dumitriu, I.E., Melville, L., Melrose, L.A., Ogden, C.A., Nibbs, R., Graham, G., Combadiere, C. \& Gregory, C.D. (2008) CX3CL1/fractalkine is released from apoptotic lymphocytes to stimulate macrophage chemotaxis. Blood,112,13,pp.5026-36.

Tyurina, Y.Y., Serinkan, F.B., Tyurin, V.A., Kini, V., Yalowich, J.C., Schroit, A.J., Fadeel, B. \& Kagan, V.E. (2004) Lipid antioxidant, etoposide, inhibits phosphatidylserine externalization and macrophage clearance of apoptotic cells by preventing phosphatidylserine oxidation. J Biol Chem,279,7,pp.6056-64.

Vandivier, R.W., Fadok, V.A., Hoffmann, P.R., Bratton, D.L., Penvari, C., Brown, K.K., Brain, J.D., Accurso, F.J. \& Henson, P.M. (2002) Elastase-mediated phosphatidylserine receptor cleavage impairs apoptotic cell clearance in cystic fibrosis and bronchiectasis. J Clin Invest,109,5,pp.661-70.

Verheye, S., Martinet, W., Kockx, M.M., Knaapen, M.W.M., Salu, K., Timmermans, J.P., Ellis, J.T., Kilpatrick, D.L. \& De Meyer, G.R.Y. (2007) Selective clearance of macrophages in atherosclerotic plaques by autophagy. J Am Coll Cardiol,49,pp.706-15.

Wakasugi, K. \& Schimmel, P. (1999) Two distinct cytokines released from a human aminoacyl-tRNA synthetase. Science,284,5411,pp.147-51.

Waldo, S.W., Li, Y., Buono, C., Zhao, B., Billings, E.M., Chang, J. \& Kruth, H.S. (2008) Heterogeneity of human macrophages in culture and in atherosclerotic plaques. Am J Pathol,172,4,pp.1112-26.

Wang, J. (2008) Beclin-1 bridges autophagy, apoptosis and differentiation. Autophagy, 4,pp.947-8.

Wei, Y.S., Lan, Y., Liu, Y.G., Meng, L.Q., Xu, Q.Q. \& Xie, H.Y. (2009) Platelet-endothelial cell adhesion molecule-1 gene polymorphism and its soluble level are associated with ischemic stroke. DNA Cell Biol,28,3,pp.151-8.

Wen, Y. \& Leake, D.S. (2007) Low density lipoprotein undergoes oxidation within lysosomes in cells. Circ Res,100,9,pp.1337-43. 
Wieten, L., Broere, F., van der Zee, R., Koerkamp, E.K., Wagenaar, J. \& van Eden, W. (2007) Cell stress induced HSP are targets of regulatory T cells: a role for HSP inducing compounds as anti-inflammatory immuno-modulators? FEBS Lett,581,pp.3716-22.

Xu, W., Roos, A., Schlagwein, N., Woltman, A.M., Daha, M.R., van Kooten, C. (2006) IL-10producing macrophages preferentially clear early apoptotic cells. Blood, 107,12,pp.4930-7.

Xu, K., Yang, Y., Yan, M., Zhan, J., Fu, X. \& Zheng, X. (2010) Autophagy plays a protective role in free cholesterol overload-induced death of smooth muscle cells. J Lipid Res, 51,pp.2581-90.

Yancey, P.G., Blakemore, J., Ding, L., Fan, D., Overton, C.D., Zhang, Y., Linton, M.F. \& Fazio, S. (2010) Macrophage LRP-1 controls plaque cellularity by regulating efferocytosis and Akt activation. Arterioscler Thromb Vasc Biol,30,4,pp.787-95.

Yang, Z. \& Klionsky, D.J. (2010) Mammalian autophagy: core molecular machinery and signaling regulation. Curr Opin Cell Biol,22,pp.124-31.

Yoshimori, T. (2004) Autophagy: a regulated bulk degradation process inside cells. Biochem Biophys Res Commun,313,pp.453-458.

Yousefi, S., Perozzo, R., Schmid, I., Ziemiecki, A., Schaffner, T., Scapozza, L., Brunner, T. \& Simon, H.U. (2006) Calpain-mediated cleavage of Atg5 switches autophagy to apoptosis. Nat Cell Biol,8,pp.1124-32.

Yousefi, S. \& Simon, H.U. (2007) Apoptosis regulation by autophagy gene 5. Crit Rev Oncol Hematol,63,pp.241-4.

Yu, M., Wang, H., Ding, A., Golenbock, D.T., Latz, E., Czura, C.J., Fenton, M.J., Tracey, K.J. \& Yang, H. (2006) HMGB1 signals through toll-like receptor (TLR) 4 and TLR2. Shock,26,2,pp.174-9.

Yvan-Charvet, L., Pagler, T.A., Seimon, T.A., Thorp, E., Welch, C.L., Witztum, J.L., Tabas, I. \& Tall, A.R. (2010) ABCA1 and ABCG1 protect against oxidative stress-induced macrophage apoptosis during efferocytosis. Circ Res,106,12,pp.1861-9 


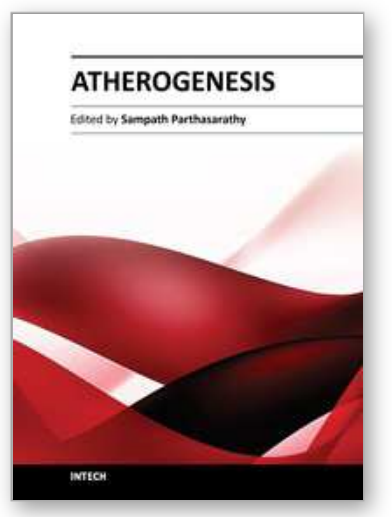

\author{
Atherogenesis \\ Edited by Prof. Sampath Parthasarathy
}

ISBN 978-953-307-992-9

Hard cover, 570 pages

Publisher InTech

Published online 11, January, 2012

Published in print edition January, 2012

This monograph will bring out the state-of-the-art advances in the dynamics of cholesterol transport and will address several important issues that pertain to oxidative stress and inflammation. The book is divided into three major sections. The book will offer insights into the roles of specific cytokines, inflammation, and oxidative stress in atherosclerosis and is intended for new researchers who are curious about atherosclerosis as well as for established senior researchers and clinicians who would be interested in novel findings that may link various aspects of the disease.

\title{
How to reference
}

In order to correctly reference this scholarly work, feel free to copy and paste the following:

Dorien M. Schrijvers, Guido R.Y. De Meyer and Wim Martinet (2012). (Auto)Phagocytosis in Atherosclerosis: Implications for Plaque Stability and Therapeutic Challenges, Atherogenesis, Prof. Sampath Parthasarathy (Ed.), ISBN: 978-953-307-992-9, InTech, Available from: http://www.intechopen.com/books/atherogenesis/auto-phagocytosis-in-atherosclerosis-implications-for-plaque-stability-and-therapeutic-challenges

\section{INTECH}

open science | open minds

\section{InTech Europe}

University Campus STeP Ri

Slavka Krautzeka 83/A

51000 Rijeka, Croatia

Phone: +385 (51) 770447

Fax: +385 (51) 686166

www.intechopen.com

\section{InTech China}

Unit 405, Office Block, Hotel Equatorial Shanghai

No.65, Yan An Road (West), Shanghai, 200040, China

中国上海市延安西路65号上海国际贵都大饭店办公楼405单元

Phone: +86-21-62489820

Fax: +86-21-62489821 
(C) 2012 The Author(s). Licensee IntechOpen. This is an open access article distributed under the terms of the Creative Commons Attribution 3.0 License, which permits unrestricted use, distribution, and reproduction in any medium, provided the original work is properly cited. 